Institute of $\mathbf{F}_{\text {ood and }} \mathbf{A}_{\text {gricultural }} \mathbf{S}_{\text {ciences }}$

\title{
Botrytis Blossom Blight of Southern Highbush Blueberry 1
}

Philip F. Harmon ${ }^{2}$

Information contained in this publication is intended to help blueberry growers in Florida identify and manage Botrytis blossom blight. For more information, search the EDIS website or contact your local University of Florida, IFAS extension agent.

\section{The Pathogen and Disease Cycle}

Botrytis blossom blight is an important disease of blueberries and several flowering ornamental plants. The fungus, Botrytis cinerea, most commonly infects and blights wounded or senescent plant tissues. As a blueberry bush blooms, corollas (the fused petal of the flowers) senesce and become quite susceptible to infection. Ideally the corolla should drop from the flower after pollination but before senescence occurs. Frost damage on tender new growth may wound the plant, delay petal drop, and facilitate infection by the fungus.

The pathogen survives well as a saprophyte on dead host and non-crop plant material. Spores of the pathogen are abundant during blueberry bloom most years. Sanitation efforts to remove diseased and infested plant materials are good horticultural practices but would not significantly limit development of this disease.



Figure 1. Corollas of southern highbush blueberry infected with Botrytis cinerea and exhibiting typical symptoms of Botrytis blossom blight. Disease has progressed into the peduncle of the center flower.

Botrytis blossom blight can spread from the corolla into the ovary and eventually into the peduncle (stem of the immature berry) (Fig. 1). During periods of high relative humidity, conidia (spores) of the fungus are produced on infected plant parts (Fig. 2). If the blight continues, an entire cluster of berries can be aborted (Fig. 3).

When disease is severe, the berry reduction can become economically important (Fig. 4). After

1. This document is PP198, one of a series of the Plant Pathology Department, Florida Cooperative Extension Service, Institute of Food and Agricultural Sciences, University of Florida. Original publication date April 2004. Visit the EDIS Web Site at http://edis.ifas.ufl.edu.

2. Philip F. Harmon, assistant professor, Plant Pathology Department, Cooperative Extension Service, Institute of Food and Agricultural Sciences, University of Florida, Gainesville, 32611.

The Institute of Food and Agricultural Sciences (IFAS) is an Equal Employment Opportunity - Affirmative Action Employer authorized to provide research, educational information and other services only to individuals and institutions that function without regard to race, creed, color, religion, age, disability, sex, sexual orientation, marital status, national origin, political opinions or affiliations. For information on obtaining other extension publications, contact your county Cooperative Extension Service office. Florida Cooperative Extension Service / Institute of Food and Agricultural Sciences / University of Florida / Larry R. Arrington, Interim Dean 


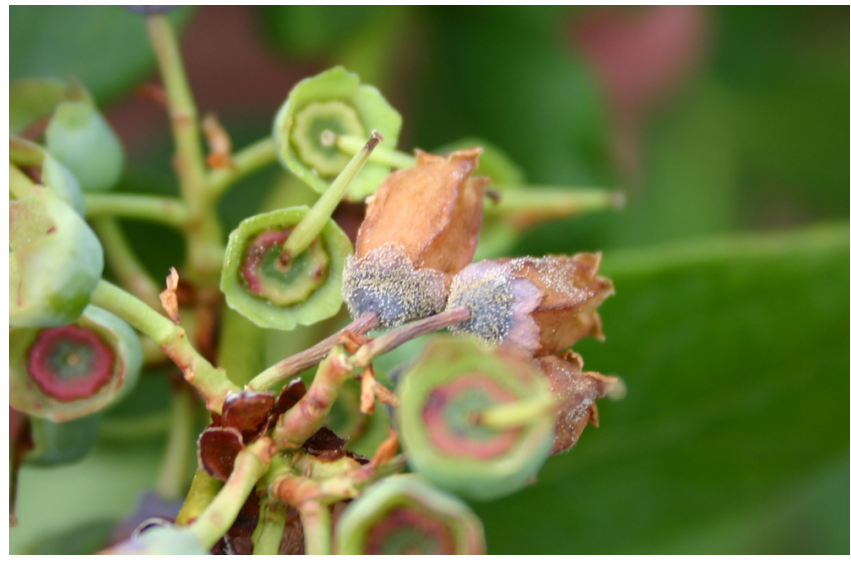

Figure 2. Gray sporulation of Botrytis cinerea is observed on corolla and calyx of southern highbush blueberry flowers after an extended period of high relative humidity. Corollas do not typically senesce and turn brown on the plant but are usually dropped after pollination while still white. Brown corollas that remain on the bush and gray sporulation are good diagnostic symptoms of Botrytis blossom blight.

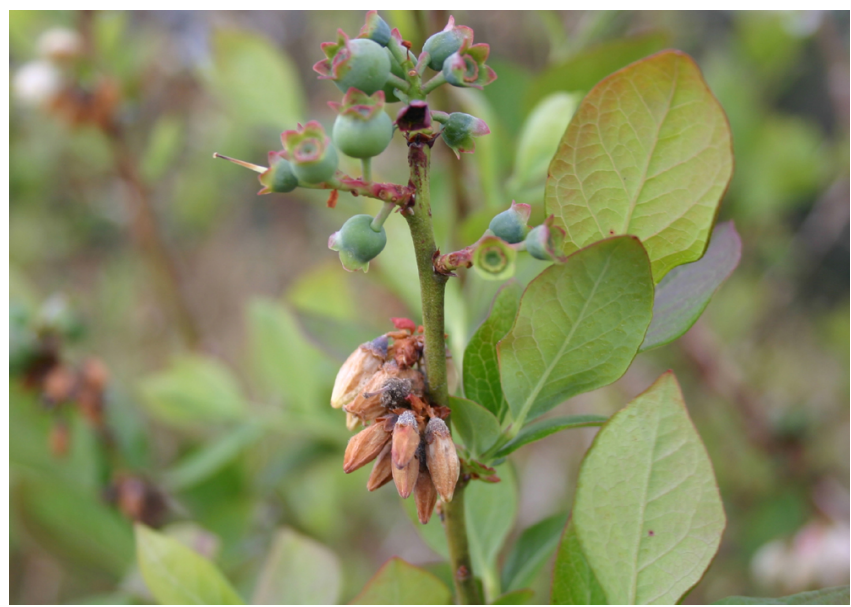

Figure 3. Severe symptoms of Botrytis blossom blight were observed on a cluster of flowers of southern highbush blueberry. The flowers that produced the immature fruits (top) developed before the cool wet period and escaped infection. Some of these fruits could be infected, but they will likely mature if no further periods of disease-favorable weather recur.

pollination of a flower and drop of the corolla, the risk of infection of the developing fruit is reduced. If progress of the blight is suppressed by environmental conditions, a fungicide application, or by plant defenses, disease progress may stop, but the fungus may lie dormant in the immature fruit. Infected berries are sometimes deformed and may develop further rot if environmental conditions later become favorable for disease (Fig. 5). If the fruit is stored cool and humid for long periods after harvest, the fungus may then cause the gray fuzzy rot commonly observed on blueberries in grocery stores. Because of the relatively short interval from harvest to retail sales in Florida, the fruit rot stage of the disease is not typically a concern.

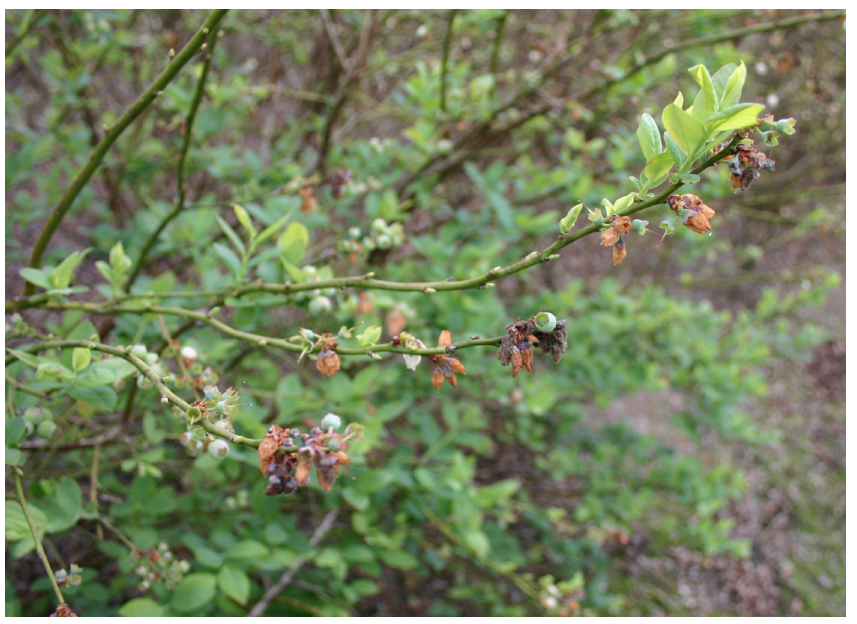

Figure 4. Many of the blighted flowers on this southern highbush blueberry will not produce fruit. When extended periods of disease favorable conditions occur during bloom, Botrytis blossom blight can reduce yield enough to impact economic return. A preventative fungicide application could have protected the blossoms during the favorable conditions and may have limited disease development.

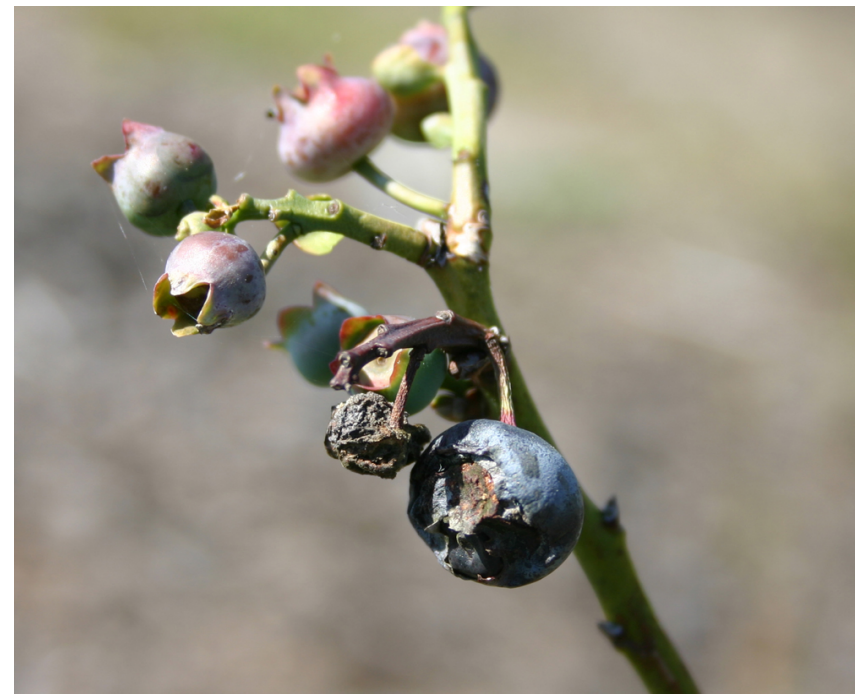

Figure 5. Some blueberry fruits rot or develop shriveled and deformed if the flowers are infected by Botrytis cinerea at bloom. Diseased berries that remain on the bush produce inoculum capable of infecting other ripening fruits.

The development of Botrytis blight, like many other foliar fungal diseases, is highly dependent on environmental conditions. Infection and disease development are favored by extended periods of high 
relative humidity. Most years, blueberries in Florida are overhead irrigated for freeze protection during bloom. While sometimes necessary, frequent overhead irrigation at this time of year increases the likelihood of Botrytis blossom blight.

Botrytis blossom blight is unusual, because disease can occur at a wide range of temperatures from as low as $32^{\circ} \mathrm{F}$, where growth of the fungus is slow, to over $70^{\circ} \mathrm{F}$. Periods of low temperatures and extended periods of high relative humidity that occur during bloom and result in more-than 24 hours of leaf wetness increase the likelihood of significant disease development.

According to Florida Automated Weather Network (FAWN) data from the Alachua location, hourly temperatures between February 24 and 27 were (on average) $9^{\circ} \mathrm{F}$ lower in 2004 than the average of the hourly temperatures recorded the previous four years. In addition to the unusually low temperatures during this period, the hourly relative humidity remained above $90 \%$ for the entire time. The extended cool and wet period was favorable for disease development and likely contributed to the severe outbreak of Botrytis blossom blight observed in Gainesville around March 4, 2004.

\section{Disease Management}

Blueberry cultivars differ in susceptibility to Botrytis blossom blight, but no one cultivar is completely resistant. In an average year in Florida, the economic loss due to Botrytis can be minimized by judicious fungicide applications and limited use of irrigation for freeze protection. Overhead irrigation extends periods of leaf wetness and favors disease development. Fungicide applications prior to, during, or immediately following extended cool wet periods during bloom can limit early infection. Untreated infections during bloom can lead to disease problems throughout the season. If Botrytis does become established at bloom, fungicide applications later in the season may be required to manage spread of the fungus to ripening berries. Applications at this time are less efficient and less effective for managing this disease than those at bloom.

Fungicides labeled for Botrytis cinerea control on blueberries in Florida and their relative efficacies are listed in Table 1. Captan is familiar to many growers and a cost-effective fungicide that will prevent infection and Botrytis blossom blight development if applied preventatively. Some of the new, site-specific, systemic fungicides listed in Table 1 have provided excellent control in university trials when applied preventatively and curatively (soon after favorable conditions but before symptoms are apparent) but have not been extensively tested on blueberries in Florida. Resistance to site-specific fungicides is a real concern with this pathogen. Resistance management strategies are included on the labels of products containing site-specific fungicides. Each of the different fungicides in Table 1 has a different mode of action and can be rotated in a resistance management plan. Always read and follow each product's specific label instructions carefully as changes may have occured since this text was written. If in doubt, contact your local county agent or university specialist for up-to-date information. Products are listed for example only. No endorsement or criticism of any product listed or omitted is intended or implied. Relative efficacy data were taken from results of trials not conducted in Florida. 
Table 1. Fungicides for control of Botrytis cinerea on blueberry.

\begin{tabular}{|c|c|c|c|c|}
\hline Common name & Trade name & Activity & $\begin{array}{c}\text { Relative e } \\
\text { prevent }\end{array}$ & $\begin{array}{l}\text { fficacy }{ }^{1} \\
\text { control }\end{array}$ \\
\hline fenhexamid $^{2}$ & Elevate $50 \mathrm{WDG}$ & contact & $\star \star \star *$ & ** \\
\hline cyprodinil ${ }^{2}$, fludioxonil & Switch 62.5 WG & local systemic & $\star * *$ & ** \\
\hline boscalid $^{2}$, pyraclostrobin ${ }^{2}$ & Pristine & local systemic & 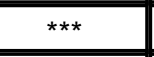 & ** \\
\hline captan & Captan 50 WP & contact & ** & * \\
\hline pyraclostrobin $^{2}$ & Cabrio EG & local systemic & * & * \\
\hline iprodione $^{2}$ & Rovral & local systemic & * & * \\
\hline \multicolumn{5}{|c|}{$\begin{array}{l}\text { f }_{* * *} \text { provides greatest efficacy under disease-favorable conditions } \\
{ }^{* *} \text { good management tool under moderate to low disease pressure } \\
{ }^{*} \text { provides some control, best used in rotation or tank mix with other chemistries } \\
{ }^{2} \text { Risk of resistance. Resistance management required for these fungicides. }\end{array}$} \\
\hline
\end{tabular}

